\title{
Utilization of mixed pond ash in integrated steel plant for manufacturing superior quality bricks
}

\author{
PIYUSH KANT PANDEY* and RAJ KUMAR AGRAWAL ${ }^{\dagger}$ \\ Bhilai Institute of Technology, Bhilai House, Durg 491 002, India \\ 'Steel Authority of India Limited, Bhilai Steel Plant, Bhilai 491 006, India
}

MS received 18 April 2002; revised 22 July 2002

\begin{abstract}
Fly ash (FA) poses serious problems to the industries. Integrated steel plants generate huge quantity of FA from their captive power plants and other furnaces. This ash is generally disposed off in the ash ponds along with other sludges and residues of steel making operations. This changes the constitution of FA and makes the brick manufacturing difficult. This paper has attempted to devise the ways for the use of this mixed ash for manufacturing mixed ash clay bricks successfully. The bricks thus made are superior in structural and aesthetic qualities and portents huge saving in the manufacturing costs with better consumer response.
\end{abstract}

Keywords. Fly ash; integrated steel plant; fly ash bricks; ash disposal; building materials.

\section{Introduction}

The problem of collection and disposal of the process residues such as the fly ash (FA) and sludges from the various industrial operations has become one of the most potent environmental problems facing the entire world. Heavy metals and variety of organic constituents are almost invariably present in trace amounts in such FA and have been reported to cause abnormally high levels of inorganic and organic pollution in Indian atmosphere (Pandey et al 1998, 1999). Most of the combustion residues do not meet the environmental standard set for their bulk applications. The airborne ash coming from the stacks or due to the drying up of the ash ponds causes severe respiratory and other ailments, visual and aesthetic problems in almost all the major industrial cities in India. FA is also considered a hazardous waste due to the probable leaching of potentially toxic substance into the surface water, ground water and soil.

Nearly $73 \%$ of India's total installed power generation capacity is thermal, of which coal-based generation is $90 \%$ - the remaining comprising diesel, wind, gas and steam. The 85 utility thermal power stations, besides the several captive power plants, use bituminous and subbituminous coal and produce large quantities of FA. The ash content of the Indian coal (30-50\%) contributes to these large volumes of FA. The World Bank has cautioned India that by 2015 , land disposal of coal ash would call for about 1000 square kilometers or one square meter of land per person (TERI 2000). Hence, there is a need to

*Author for correspondence effectively use fly ash. Therefore, FA is examined for its suitability in applications such as ash alloys, ceramic tiles, fire bricks, insulation products, mineral wool, ceramic fibre, distemper, synthetic wood, fire abatement applications, soil conditioner, mine filling, roads and embankment, cement etc.

Utilization of FA can result not only in reducing the magnitude of the environmental problems, but also to exploit FA as a raw material for value added products (and conserve traditional materials), and for extraction of valuable materials. Amongst many uses of FA, its use as building material is particularly suitable because it is anticipated, that there would be considerable shortfall in production of various building materials. According to a study (TIFAC 2000), there is a huge short-fall in the production of bricks - to the tune of 25 billion bricks on an estimated demand of 100 billion bricks per year in India as on today. Many attempts have been made by various research institutions in India for utilization of FA in recognition of the size of FA utilization/disposal problem. Further, the technologies appropriate for Indian FA are also available. Still, India utilizes hardly about $10 \%$ of the total FA generated (Kumar et al 1999, 2000; TIFAC 2000). Thus, India needs to deal with about 100 million ton unutilized FA every year now.

To tackle the problem and encourage the use of FA for making building materials, the Government of India has imposed restriction (Gazette notification of 14th September 1999, issued by the Ministry of Environment and Forests) on brick manufacturers to use at least $25 \%$ of ash on weight-to-weight basis if the brick kiln is located within a radius of $50 \mathrm{~km}$ from coal or lignite based thermal power plants. The demand for bricks is expected to 
be about 100 billion per year by the turn of the century. Even if only $50 \%$ of the estimated demand of 100 billion bricks per year is met from FA for productive use, it will help in saving alternate resources and reducing environmental hazard to that extent. In addition, it would save thousands of hectares of land from being used as pond area, this still does not account for the potential of using other industrial wastes like red-mud (Raju et al 1996; Kumar and Sharma 1999).

Every integrated steel plant in India has its own captive power plant, which generates huge quantity of ash. This ash is often dumped along with other process wastes in dumping pits. We have attempted to use the various wastes in an integrated steel plant to see if they can be used to produce superior quality ash bricks, which would be more agreeable to the consumer because of the quality and aesthetics. The pond ash in steel plant is different from pure FA, since it is mixed with blast furnace and twin hearth furnace sludge. An estimation of optimum proportion of pond ash and clay in the manufactured bricks and its strength is necessary. The results of such tests will be helpful in persuading the local brick manufacturers to use pond ash as a raw material.

\section{Experimental}

The FA and mixed FA samples were obtained from various ashes and sludge dumping ponds of Bhilai Steel Plant, Bhilai. The samples were analysed to find out their chemical composition and loss on ignition (LOI). For use as a control, FA bricks and normal clay bricks were also manufactured. For the purpose, dry FA was obtained from the power plant. One part by weight of hydrated lime and sand was added to about eight parts by weight of FA. The material was then fed to a mixer for making a homogeneous mixture with the addition of water and was allowed to stand overnight. The material was then fed to a hydraulic press where it was pressed at $180-200 \mathrm{~kg} / \mathrm{cm}^{2}$ to get moulded green bricks. These green bricks were air dried for $24 \mathrm{~h}$. The green bricks were then cured in an autoclave and subjected to steam curing at $10-12 \mathrm{~kg} / \mathrm{cm}^{2}$ for $6 \mathrm{~h}$. For the preparation of mixed-ash bricks different proportions of clay with pond-ash were mixed in a $1.5 \mathrm{~T}$ motorized mixer and four samples were prepared. These mixes were enriched with different proportions of water according to the plasticity of clay. No chemical binder was used in this process. As the mix contained clay, press pressure was reduced to $100 \mathrm{~kg} / \mathrm{cm}^{2}$. Four categories of bricks of differing proportion were made. The curing of these bricks was carried out at different temperatures viz. $200^{\circ}, 800^{\circ}$ and $1200^{\circ} \mathrm{C}$. These bricks were tested for apparent porosity, bulk density, weight, compressive strength and water absorption.

\section{Results and discussion}

The chemical analysis of FA and other mixed ashes obtained from various ash ponds of Bhilai Steel Plant shows that the percentage of iron is very high in the ash pond where the sludge from twin hearth furnace and power plant no. II is present, but it is poor in silica content (table 1).

Table 2 shows the green strength of the four categories of mixes and it was found that the addition of $40-50 \%$ pond ash with $12-15 \%$ of water provides good green strength.

Mullite $\left(3 \mathrm{Al}_{2} \mathrm{O}_{3} \cdot 2 \mathrm{SiO}_{2}\right)$ is responsible for the compressive strength of bricks. The aim of this work was to synchronize mullite $\left(3 \mathrm{Al}_{2} \mathrm{O}_{3} \cdot 2 \mathrm{SiO}_{2}\right)$ generation in the bricks by sintering FA with alumina. Under appropriate conditions, the ash and $\mathrm{Al}_{2} \mathrm{O}_{3}$ react to form mullite phase during sintering while producing the ordinary FA brick. However, this does not happen normally in the case of steel plant pond-ash because the FA is mixed with blast furnace and steel melting sludges and the higher percentages of iron fouls the reaction with concomitant decrease in the silica content. Addition of clay in proper percentage is the answer to the problem as observed by us.

Figure 1 shows that the FA brick made using lime as a binder is black in colour and smooth in finish. The crushing strength $\left(85 \mathrm{~kg} / \mathrm{cm}^{2}\right)$ was comparable to the ordinary red (clay) bricks and the water absorption (18\%) was below the stipulated values (IS: 12894-1990, Fly ashlime bricks). However, the black colour of these bricks is the biggest lacunae in popularization of these bricks inspite of all other attendant benefits.

The mixed pond ash and clay bricks have provided very encouraging results particularly with $50+$ and 60 category composition. Sample numbers 50 and $60+$ showed poor green strength and hence discarded. The $50+$ and 60 category bricks have shown good green strength. Therefore, these samples were air dried for

Table 1. Chemical constitution of the ash in three ash ponds of Bhilai Steel Plant.

\begin{tabular}{lcccccc}
\hline Components & $\% \mathrm{SiO}_{2}$ & $\% \mathrm{Al}_{2} \mathrm{O}_{3}$ & $\% \mathrm{CaO}$ & $\% \mathrm{MgO}$ & $\% \mathrm{Fe}(\mathrm{T})$ & $\%$ LOI \\
\hline Fly ash & 58 & 22 & 1 & $0 \cdot 8$ & 2 & 8 \\
Fly ash + BF sludge & 58 & 24 & $1 \cdot 6$ & $2 \cdot 25$ & 8 & 8 \\
Fly ash + THF sludge & 24 & $10 \cdot 5$ & 1.4 & 0.5 & 33 & $11 \cdot 2$ \\
\hline
\end{tabular}

$\mathrm{BF}=$ blast furnace $\mathrm{THF}=$ twin hearth furnace. 
$24 \mathrm{~h}$, which further improved the strength. These bricks were cut into three pieces and further tests were carried out by curing at different temperatures. The first batches of samples were kept at $200^{\circ} \mathrm{C}$ for $4 \mathrm{~h}$ in an in-house built gas fired furnace. The black colour of samples changed to grey-brown and crushing strength increased. The texture and surface of the bricks was smooth (figure 2). On dropping the brick on a steel plate from $2 \mathrm{M}$ height, the sample did not break from any angle. The

Table 2. Green strength of various mixes.

\begin{tabular}{lcccc}
\hline $\begin{array}{l}\text { Sample } \\
\text { category }\end{array}$ & $\begin{array}{c}\% \\
\text { Clay }\end{array}$ & $\begin{array}{c}\% \text { Pond } \\
\text { ash }\end{array}$ & $\begin{array}{c}\% \\
\text { Water }\end{array}$ & $\begin{array}{c}\text { Green } \\
\text { strength }\end{array}$ \\
\hline 50 & 50 & 50 & 10 & Poor $\left(<10 \mathrm{~kg} / \mathrm{cm}^{2}\right)$ \\
$50+$ & 50 & 50 & 15 & Good $\left(\geq 10 \mathrm{~kg} / \mathrm{cm}^{2}\right)$ \\
60 & 60 & 40 & 12 & Good $\left(\geq 10 \mathrm{~kg} / \mathrm{cm}^{2}\right)$ \\
$60+$ & 60 & 40 & 18 & Poor $\left(<10 \mathrm{~kg} / \mathrm{cm}^{2}\right)$ \\
\hline
\end{tabular}

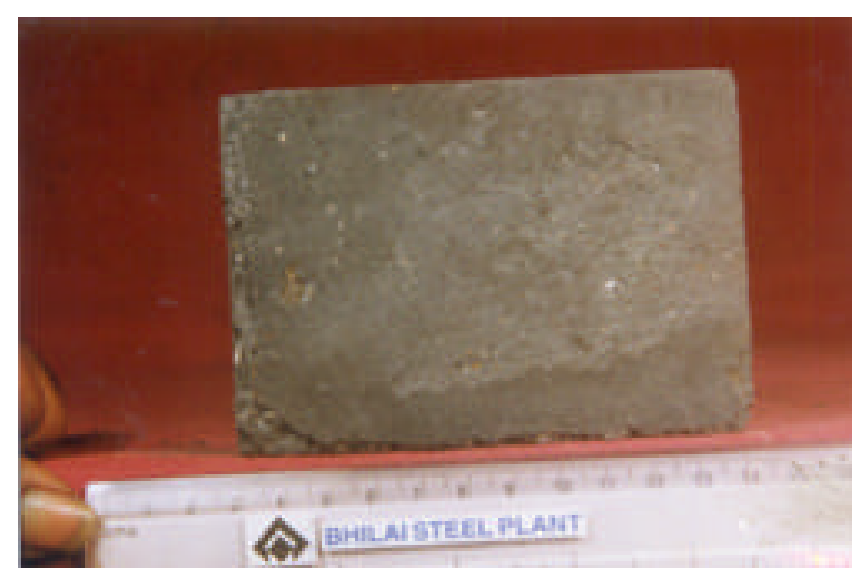

Figure 1. Normal fly ash brick manufactured by using FA, clay and lime binder.

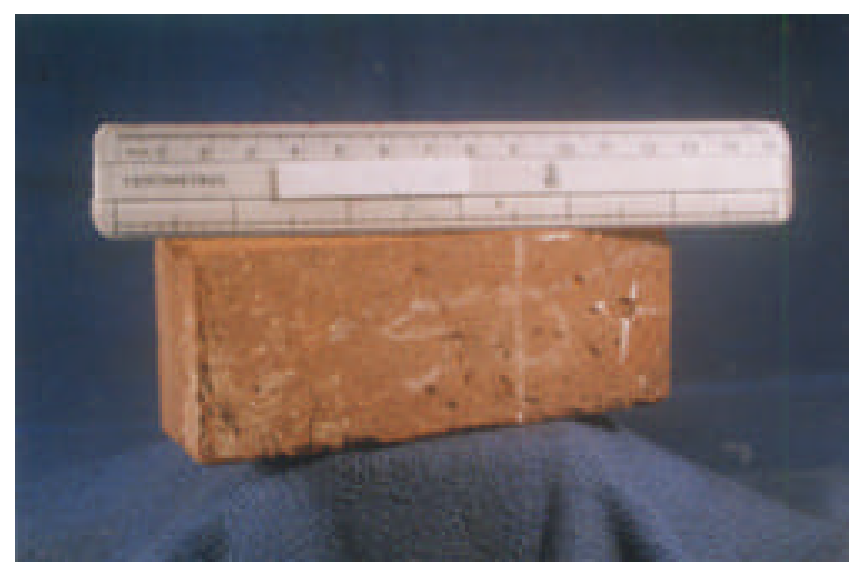

Figure 2. Mixed pond-ash clay bricks obtained on curing at $200-800^{\circ} \mathrm{C}$. second batches of samples were heated to $800^{\circ} \mathrm{C}$ in a muffle furnace. Samples were slowly cured and temperature was ramped to $800^{\circ} \mathrm{C}$ in $4 \mathrm{~h}$. After maintaining it for two more $\mathrm{h}$ at this temperature, the furnace was allowed to be cooled slowly. This process changed the brick colour to red-brown with weight stabilization due to complete moisture removal. No crack was visible in the bricks. The third batch was put in the hearth of muffle furnace and temperature was increased slowly to $1200^{\circ} \mathrm{C}$ in $6 \mathrm{~h}$. It was kept for $2 \mathrm{~h}$ at $1200^{\circ} \mathrm{C}$ zone and then cooled slowly. The cooling time was about $8 \mathrm{~h}$. This heating caused most of the samples to be cracked and it caused patchy agglomeration of iron metal and slag in the bricks (figure 3). The microstructure (figure 4) confirms the distribution of iron and slag in the mix, which exerts a beneficial impact on the strength of the bricks thus prepared.

Bricks cured at $800^{\circ} \mathrm{C}$ were tested for apparent porosity, bulk density, crushing strength and water absorption

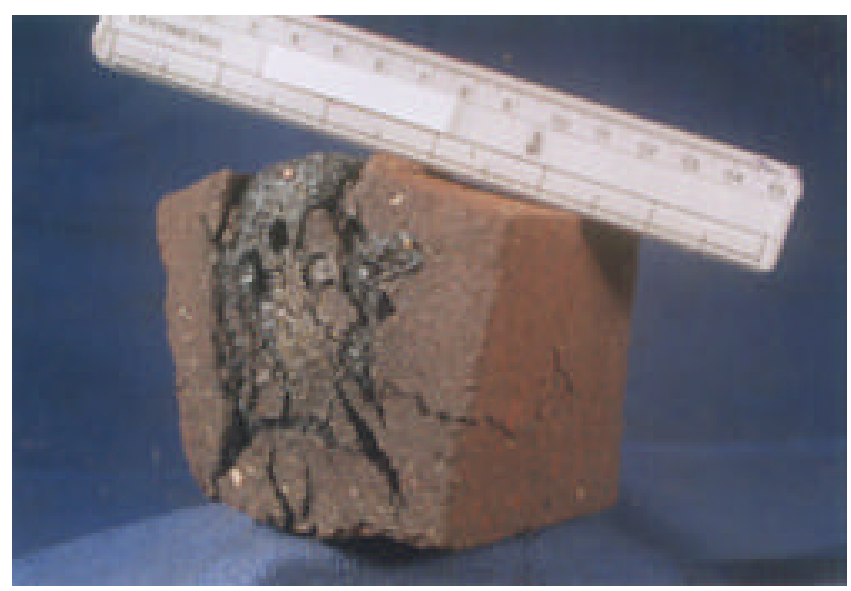

Figure 3. Mixed pond-ash clay bricks obtained on curing at $1200^{\circ} \mathrm{C}$ showing agglomeration of iron and slag.

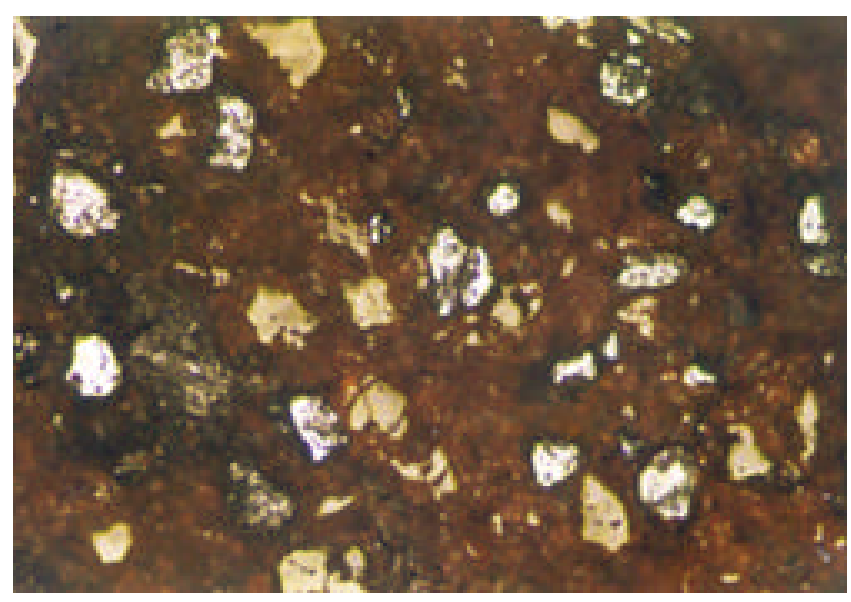

Figure 4. Microstructure of mixed pond-ash clay bricks obtained on curing at $1200^{\circ} \mathrm{C}$ showing agglomeration of iron and slag. 
Table 3. Structural properties of mixed pond-ash clay bricks.

\begin{tabular}{lcccc}
\hline Sample & $\begin{array}{c}\text { Apparent po- } \\
\text { rosity }\end{array}$ & $\begin{array}{c}\text { Bulk density } \\
(\mathrm{g} / \mathrm{cc})\end{array}$ & $\begin{array}{c}\text { Cold crushing strength } \\
\left(\mathrm{kg} / \mathrm{cm}^{2}\right): \text { minimum }\end{array}$ & $\begin{array}{c}\text { Water absorption } \\
(\%): \text { maximum }\end{array}$ \\
\hline Mixed pond-ash clay 50 + category & $34 \cdot 9$ & $2 \cdot 14$ & $99 \cdot 2$ & $16 \cdot 3$ \\
Mixed pond-ash clay 60 category & $34 \cdot 3$ & $2 \cdot 1$ & $95 \cdot 2$ & $16 \cdot 2$ \\
Normal red clay brick locally available & $34 \cdot 0$ & $1 \cdot 68$ & 70 & 20 \\
IS stipulation fly ash bricks & - & - & 75 & 20 \\
$\quad$ (IS: 12894-1990) Class 7.5 bricks & - & - & 75 & 20 \\
IS stipulation red clay bricks & & & & \\
$\quad$ (IS: 1077-1986) & & & & \\
Class 7.5 common burnt clay bricks & &
\end{tabular}

tests. On all counts, the mixed pond-ash clay bricks were found superior to the normal clay red bricks. The cold crushing strength was higher and water absorption was on lower side compared to the normal red clay bricks (table 3).

Based on the superior quality, strength and aesthetic merits, mixed pond-ash clay bricks have a greater potential for wider acceptance of the consumers. The large production of the fly ash in the integrated steel plants of India (table 4) and its present mode of disposal as identified by us (table 5) attest to the need of adoption and popularization of mixed pond-ash clay bricks.

The production of mixed pond-ash clay bricks has many advantages compared to the normal bricks. First, it has low cost of production due to fuel saving because of the presence of unburnt carbon (up to 15\%) present in some pond ash. Secondly, the process is less labour intensive and thirdly the smooth surface finish and the absence of cracks provides a better construction quality with lower consumption of the cement mortar. These bricks do not require any plastering. The only disadvantage which has been noted by us is the heavier weight of these bricks compared to the normal bricks. Still, this could be a rather beneficial feature depending on the application of these bricks.

As far as the commercialization of the process and its cost is concerned, we have noted that heating at $\geq 200^{\circ} \mathrm{C}$ is sufficient for the marketable product the properties of which are comparable to that of the product heated at $800^{\circ} \mathrm{C}$. Hence, heating at $800^{\circ} \mathrm{C}$ is not necessary and this clay-FA bricks can be manufactured in the similar way as the normal red clay bricks. Based on cost saving in using FA because of the presence of unburnt carbon, avoidance of the digging costs and lower breakages of the bricks, the landed cost of the mixed FA clay bricks is less than Rs 900 per thousand compared to the normal red clay bricks which costs between 1200 to 2000 per thousand in Chhattisgarh area. The cost of the normal red clay bricks is probably lowest in Chhattisgarh compared to other parts of India because of the lower demand and cheap availability of labour and land. Accordingly, the FA utilization may be even more beneficial than what we have calculated.
Table 4. FA generation in SAIL plants.

\begin{tabular}{lcc}
\hline Steel plant & $\begin{array}{c}\text { FA generation } \\
\text { (ton) }\end{array}$ & $\begin{array}{c}\text { Generation rate } \\
\text { of crude steel }(\mathrm{kg} / \mathrm{T})\end{array}$ \\
\hline Bhilai Steel Plant & 180838 & $91 \cdot 2$ \\
Durgapur Steel Plant & 120379 & $140 \cdot 8$ \\
Rourkela Steel Plant & 437834 & $594 \cdot 6$ \\
Bokaro Steel Plant & 490750 & $230 \cdot 7$ \\
Indian Iron \& Steel Co. & 71131 & $182 \cdot 2$ \\
SAIL (Total) & 1300932 & $20 \cdot 16$ \\
\hline
\end{tabular}

Table 5. FA recycled, sold and dumped in integrated steel plants of India.

\begin{tabular}{lccc}
\hline Plant & $\begin{array}{c}\text { FA recycled } \\
(\%)\end{array}$ & $\begin{array}{c}\text { Sold } \\
(\%)\end{array}$ & $\begin{array}{c}\text { Dumped } \\
(\%)\end{array}$ \\
\hline Bhilai Steel Plant & - & - & 100 \\
Durgapur Steel Plant & - & - & 100 \\
Rourkela Steel Plant & $25 \cdot 6$ & - & 74.4 \\
Bokaro Steel Plant & - & - & 100 \\
Indian Iron \& Steel Co. & - & $82 \cdot 8$ & 17.2 \\
SAIL plants (Total) & 8.6 & 4.5 & 86.9 \\
\hline
\end{tabular}

The cementitious properties of FA are certainly contributing to the compressive strength of the bricks. Siliceous by-products with pozzolanic properties have the potential of increasing the durability of any structure or cement paste made with such a product. This is due to the dense microstructure promoted by the pozzolanic reaction, which reduces considerably the ingress of aggressive agents from the environment through the interconnected pore channels (Mehta 1986; Uchikawa 1986; Lorenzo 1993; Goni et al 1994; Guerrero 2000). Based on this we hypothesize that the bricks made by us will be more resistant to the aggressive environment. The preliminary results obtained by us substantiate this premise and further research in the area is being conducted.

\section{Conclusions}

Bricks manufactured by using mixed pond-ash of an integrated steel plant have been found to be cheap, superior 
in structural and aesthetic qualities. These bricks can be manufactured in the routine manner following the existing method of red clay bricks production. The cost saving in using FA is due to the presence of unburnt carbon causing a better firing, avoidance of the digging costs, lower breakages of the bricks and savings in plastering costs. This paper has established that the use of mixed pond-ash in the range of $40-50 \%$ remaining being the clay provides a very viable option of the use of huge quantities of FA now being dumped by the Indian steel industry.

\section{Acknowledgement}

The authors acknowledge the guidance and support extended by Shri B M K Bajpai, Bhilai Steel Plant, Bhilai.

\section{References}

Goni S, Lorenzo M P and Sagrera J L 1994 Cem. Concr. Res. 241403

Guerrero A, Hernandez M S and Goni S 2000 Waste Mgt. 2051

Kumar V and Sharma P 1999 Fly ash management in iron and steel industry; Proceedings of international conference on environmental and waste management (Jamshedpur: NML)

Kumar V, Sharma P and Jha C N 1999 Fly ash: a fortune for the construction industry; Proceedings of the international conference on waste and by-products as secondary resources for building materials (New Delhi: BMTPC)

Kumar V, Mathur M and Kharia S P 2000 FA management: Vision for the new millennium, Proceedings of 2nd international conference on fly ash disposal and utilization (New Delhi: FAM \& CBIP)

Lorenzo M P 1993 The effect of two kinds of Spanish fly ashes on the microstructure and durability of the hydrated Portland cement paste, Ph.D. thesis, University Complutense, Madrid, Spain

Pandey P K, Patel K S and Subrt P 1998 Sci. Total Environ. 215123

Pandey P K, Patel K S and Lenicek J 1999 Env. Monit. and Asses. 59287

Raju V S, Dutta M, Seshadri V, Agarwal V K and Kumar V (eds) 1996 Ash ponds and ash disposal systems (New Delhi: Narosa Publishing House)

TERI, Tata Energy Research Institute 2000 Managing fly ash TIFAC, Technology Information, Forecasting \& Assessment Council 2000 Fly ash bricks TMS085 (New Delhi: TIFAC)

Mehta P K 1986 Concrete, structure, properties and materials (ed.) W S Hall (New Jersey: Prentice-Hall)

Uchikawa H 1986 Proc. 8th Int. Congr. Chem. Cem. 1249 